\title{
Experimental studies on the transfer of dissolved solutes from soil into surface runoff on loess slopes in China
}

\author{
Wencai Dong ${ }^{1}(\mathbb{D}) \cdot$ Chengpeng $\mathrm{Cao}^{2} \cdot$ Xianbing Meng $^{3} \cdot$ Quanjiu Wang $^{4} \cdot$ Qiang Fu $^{1}$
}

Received: 27 February 2018 / Accepted: 19 September 2018 / Published online: 28 September 2018

(c) The Author(s) 2018

\begin{abstract}
Overland flow and concomitant solute transport were a major source of pollutants in receiving surface water. The objective of this study was to better understand the mechanisms of soil erosion, solute transport from soil to runoff and lost via runoff, especially the effects of cumulative infiltration before the runoff generation. Laboratory experiments were conducted with three initial soil moisture contents, three rainfall intensities and three slope gradients to evaluate the effects of these variables and their interactions on soil erosion and solute losses to the runoff. The results indicated that if infiltration could be facilitated, the loss of solutes could be increased. Rainfall intensity increases the mass of sediment carried away by the runoff, decreases the time required for runoff formation and increases the solute content in the surface layer. Both the masses of solute and sediment in the runoff increase as the slope gets steeper. The rainfall splash and infiltration before runoff generation were found to play important roles in soil erosion and solute lost to the runoff, if ponding time could be prolonged, the loss of solutes could be reduced. The relationship between cumulative infiltration during ponding time and the average solute concentration in the runoff can be well described by the linear equations. The average solute concentration in the runoff was positive linear correlation with solute concentration in the soil surface layer at the time when runoff took place.
\end{abstract}

Keywords Initial soil moisture content $\cdot$ Rainfall intensity $\cdot$ Slope gradient $\cdot$ Solute transport $\cdot$ Ponding time

\section{Introduction}

The release and migration of nutrients, pesticides and other chemicals from agricultural lands into the surface runoff and the groundwater during periods of heavy rainfall or surface irrigation have caused severe soil quality degradation and water pollution in China's Loess Plateau. Solutes transported in surface water flows can pollute surface water bodies and the groundwater. Significant fractions of the N(8-80\%)

Wencai Dong

wencai80923@163.com

$\triangle$ Qiang Fu

fuqiang232302@163.com

1 College of Water Conservancy and Architecture, Northeast Agricultural University, Harbin 150030, Heilongjiang, China

2 College of Water Resources and Civil Engineering, China Agricultural University, Beijing 100083, China

3 College of Resources and Environment, Northeast Agricultural University, Harbin 150030, Heilongjiang, China

4 Institute of Water Resources, Xi' an University Technology, Xi' an 710048, Shannxi, China and $\mathrm{P}(7-30 \%)$ lost from agricultural land are carried away in solution (Schuman et al. 1973a, b; Menzel et al. 1978; McDowell et al. 1984). Ahuja et al. (1981) studied this phenomenon, using ${ }^{32} \mathrm{P}$ as a tracer; they planted samples of the radioisotope on the soil surface and at depth intervals of $5 \mathrm{~mm}$ in different soil boxes. Their results showed that the degree of interaction between incident droplets, liquid and solid material was at its highest on the surface and decreased very rapidly with depth. Wang et al. (1998, 2002a, b) carried out the laboratory experiments to compare the various methods for calculating the depth at which raindrops and the soil surface interact, and then developed the equivalent interacting depth mode on the basis of their findings. These authors also observed that under the soil-eroding conditions encountered on the Loess Plateau, the relationship between the runoff solute content and time can be accurately modeled using a power function. Wallach et al. (2001) analyzed the relationship between the initial soil moisture, rainfall intensity and the solute content in the runoff. They pointed out that the initial soil moisture content has a pronounced influence on the surface runoff concentration due to its effect on the ponding time. The transfer of soil nitrogen, phosphorus 
and potassium by surface runoff has been studied using simulated rainfall (Wang et al. 2006). Walter et al. (2007) used three soil types under three different infiltration conditions to test the mechanistic models proposed by Gao et al. (2004) and discovered that infiltration dramatically reduces both the depth of raindrop penetration into the soil and the depth of the so-called mixing zone. Guo et al. (2010a, b) performed indoor and outdoor experiments on the transport of sediments and solutes in the runoff from stone-covered soil surfaces. Several physical-based models were refined and applied to describe the process of solute transport into runoff on loessial slope land (Dong et al. 2013; Dong and Wang 2013; Yang et al. 2015, 2016). In the indoor experiments, an interaction was observed between the effects of rainfall splash and water scouring on the transport of sediment and solutes in the runoff. All their results suggested that both rainfall intensity and the scouring inflow rate play important roles in runoff formation, soil erosion and solute transport in the surface runoff.

A lot of researches had been conducted with the aim of identifying the mechanisms by which solutes are transferred into the surface runoff on sloped land, but the full details of the transfer of soil solutes into the overland flow remain unclear, especially the effects of cumulative infiltration before the runoff generation. The objectives of this study were (1) to analyze the relationship between the cumulative infiltration before runoff formation and solute losses to the runoff; (2) to investigate the relationship between runoff solute concentrations and the initial soil moisture content, the rainfall intensity and the slope gradient.

\section{Materials and methods}

The experiment was set up the same with Dong et al. (2013) in the laboratory for artificial rainfall simulation at the Institute for Soil and Water Conservation of the Chinese
Academy of Sciences, in the Shaanxi province of China. The basic component of the experiment was a rain simulator, which could generate variable rainfall intensity; the nozzles used to simulate rainfall were $15.00 \mathrm{~m}$ from the soil surface. Six steel soil flumes were used; the flumes were $1.00 \mathrm{~m}$ long, $0.40 \mathrm{~m}$ wide and $0.50 \mathrm{~m}$ high. They were filled with soil to a depth of $0.35 \mathrm{~m}$; this depth allows infiltration to occur without causing the bottoms of the flumes to become dank while leaving a 0.15 -m-high 'lip' above the soil level to prevent water losses due to splashing. The flumes' angle of inclination could be adjusted between $0^{\circ}$ and $30^{\circ}$. Schematic of the experimental apparatus and set up are shown in Fig. 1.

Three treatments were established to study on the relationship between solution concentrations in the runoff and the initial soil moisture content, the rainfall intensity and the gradient of slope. In treatment 1 , three initial soil moisture levels $5 \%, 15 \%$ and $20 \%$ gravimetrically were used to study the influence of the initial soil moisture content on solute loss with a rainfall rate of $90 \mathrm{~mm} / \mathrm{h}$ and a slope gradient of $5^{\circ}$. Treatment 2 was designed to investigate the influence of variation in the rainfall intensity on the runoff solute concentration; three different rainfall intensities $(60 \mathrm{~mm} / \mathrm{h}$, $96 \mathrm{~mm} / \mathrm{h}$ and $129 \mathrm{~mm} / \mathrm{h}$ ) were examined with an initial soil moisture content of $10 \%$ (gravimetric) and a slope gradient of $5^{\circ}$. Treatment 3 was designed to assess the influence of the slope gradient; slopes of $5^{\circ}, 15^{\circ}$ and $25^{\circ}$ were investigated, with a rainfall intensity of $90 \mathrm{~mm} / \mathrm{h}$ and an initial (gravimetric) soil moisture content of 10\%. Each treatment ran three times.

The soil used in the experiments was collected from nonagricultural land in Yangling, in China's Shaanxi province. Selected physical and chemical properties of the soil are given in Table 1.

The original soil was passed through a $4.00-\mathrm{mm}$ aperture sieve to remove coarse rock and debris and air-dried (approximately $2 \%$, gravimetrically). Potassium bromide was used as a tracer. It was dissolved in water and added to
Fig. 1 Schematic of the experimental apparatus and set up

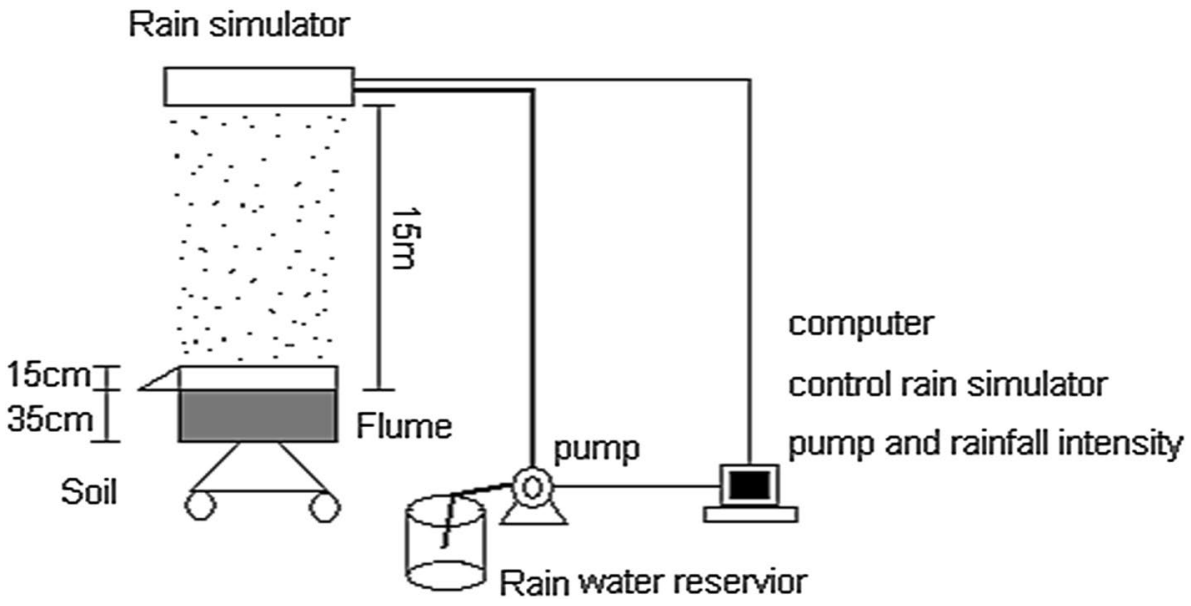

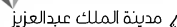

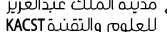


Table 1 Selected soil properties

\begin{tabular}{|c|c|c|c|c|c|c|c|c|c|c|}
\hline \multirow[t]{3}{*}{ Soil } & \multicolumn{3}{|c|}{ Particle size distribution (\%) } & \multirow{3}{*}{$\begin{array}{l}\text { Organic matter } \\
\mathrm{g} / \mathrm{kg}\end{array}$} & \multirow{3}{*}{$\begin{array}{l}\mathrm{CaCO}_{3} \\
\mathrm{~g} / \mathrm{kg}\end{array}$} & \multirow{3}{*}{$\begin{array}{l}\text { CEC } \\
\mathrm{cmol} / \mathrm{kg}\end{array}$} & \multirow{3}{*}{$\begin{array}{l}\text { Total } \\
\text { phospho- } \\
\text { rus } \\
\mathrm{g} / \mathrm{kg}\end{array}$} & \multirow{3}{*}{$\begin{array}{l}\text { Total potassium } \\
\mathrm{g} / \mathrm{kg}\end{array}$} & \multirow{3}{*}{$\begin{array}{l}\text { Total nitrogen } \\
\mathrm{g} / \mathrm{kg}\end{array}$} & \multirow[t]{3}{*}{$\mathrm{pH}$} \\
\hline & Clay & Silt & Sand & & & & & & & \\
\hline & $<0.002$ & $0.002-0.05$ & $>0.05$ & & & & & & & \\
\hline Loam & 31.65 & 64.03 & 4.32 & 9.31 & 26.80 & 21.24 & 1.10 & 18.62 & 0.71 & 8.35 \\
\hline
\end{tabular}

the test soils based on their designed soil water content and potassium bromide concentration; the soil was then thoroughly mixed. The soil flume was filled with the prepared soil sample layer by layer, to achieve a dry bulk density of $1.35 \mathrm{gcm}^{-3}$, gently tamped with a ferric block to achieve the desired density. Taking the boundary effect into account, we coated about $0.1-\mathrm{cm}$-thick glass gum on the wall from 0 to $10 \mathrm{~cm}$ along the flume, filled with soil before the solidification of the glass gum, and the samples were collected as close as possible to the middle of the flume. To obtain a flat surface, a sharp-edged straight blade was used to remove excess soil. The soil surface was covered with plastic cloth for around $24 \mathrm{~h}$ to make the soil moisture and solute mixing uniformity in the soil profile, after which the rainfall experiment was carried out. During the experiment, outflow from one of the holes in the flume was collected into plastic containers once per minute in order to measure the amount of runoff and its sediment and solute concentrations. Immediately after the rainfall was finished, soil samples were taken along a vertical section at $10-\mathrm{mm}$ intervals in order to analyze the water content and solute concentration within the soil profile. The bromide content in the runoff and soil samples was measured with an ionometer (Model WL-15B, Shanghai Jingsheng Instrument Co., LTD, China) and the soil water content was measured by drying (Dong and Wang 2013), and the sediment was isolated by filtration on filter paper and weighed after drying.

\section{Results and discussion}

\section{The effect of initial soil moisture on the runoff volume, sediment mass and solute losses to the runoff}

The initial soil moisture content affects soil infiltration and the cohesion of soil particles; the degree of infiltration has a profound impact on the mass of sediment and the concentration of solutes in the runoff (Walter et al. 2007). Figure 2 shows that the runoff volume, cumulative infiltration, sediment mass and solute content for different initial soil moisture contents change with time. The results indicated that higher initial soil moisture contents were associated with great runoff volumes per unit time (Fig. 2a), less cumulative infiltration (Fig. 2b), less the mass of sediment in the runoff (Fig. 2c) and the higher the solute content in the runoff (Fig. 2d). Comparison of Fig. 2a with d shows that both the solute content in the runoff and the runoff volume stabilize around $13 \mathrm{~min}$ after the initiation of runoff; this implies that the runoff volume affects the solute content in the runoff and that the initiation of runoff is controlled by infiltration. Therefore, the initial soil moisture content plays a major role in determining the extent of the solute losses to the runoff. When the initial soil moisture content was $15 \%$, the solute concentration in the runoff was about 1.51 times greater than that observed when the initial soil moisture content was 5\%; when the initial soil moisture content was $25 \%$, the solute content in the runoff was 1.12 times that when it was $15 \%$. The initial soil moisture content had a pronounced influence on infiltration and the timing of the formation of the runoff (Table 2). The time to ponding was $2.83,1.83$ and 1.21 min under initial soil moisture content conditions of 5, 15 and $20 \%$, respectively. Ponding time decreased with increasing initial soil moisture content, leading to cumulative infiltration decreasing over ponding time (Table 2). When the initial soil moisture levels were low, a relatively large amount of time elapsed before the runoff forms, during which the dissolved soil chemicals on the soil surface migrate downward with the infiltrating water. This decreases the subsequent soil chemical flux into the overland flow. The initial soil moisture content thus strongly affects the solute concentration in the runoff.

\section{The effect of rainfall intensity on the runoff volume, sediment mass and solute losses to the runoff}

Table 3 shows the time between rainfall initiation and runoff formation and the cumulative infiltration during this time at different rainfall intensities. With increasing rainfall intensity $(60 \mathrm{~mm} / \mathrm{h}, 96 \mathrm{~mm} / \mathrm{h}$ and $129 \mathrm{~mm} / \mathrm{h})$, ponding time gradually decreased (3.98, 2.41 and $1.72 \mathrm{~min}$ ) and cumulative infiltration during ponding time decreased (4.00, 3.84 and $3.66 \mathrm{~mm}$ ) (Table 3 ). The rainfall intensity determined the supply of water to the system and contributes to the water's ability to cause erosion. All other things being equal, the heavier the rainfall intensity, the greater the runoff volume and the erosion capacity of rainfall splashes and the water flow. Heavier rainfall intensities 

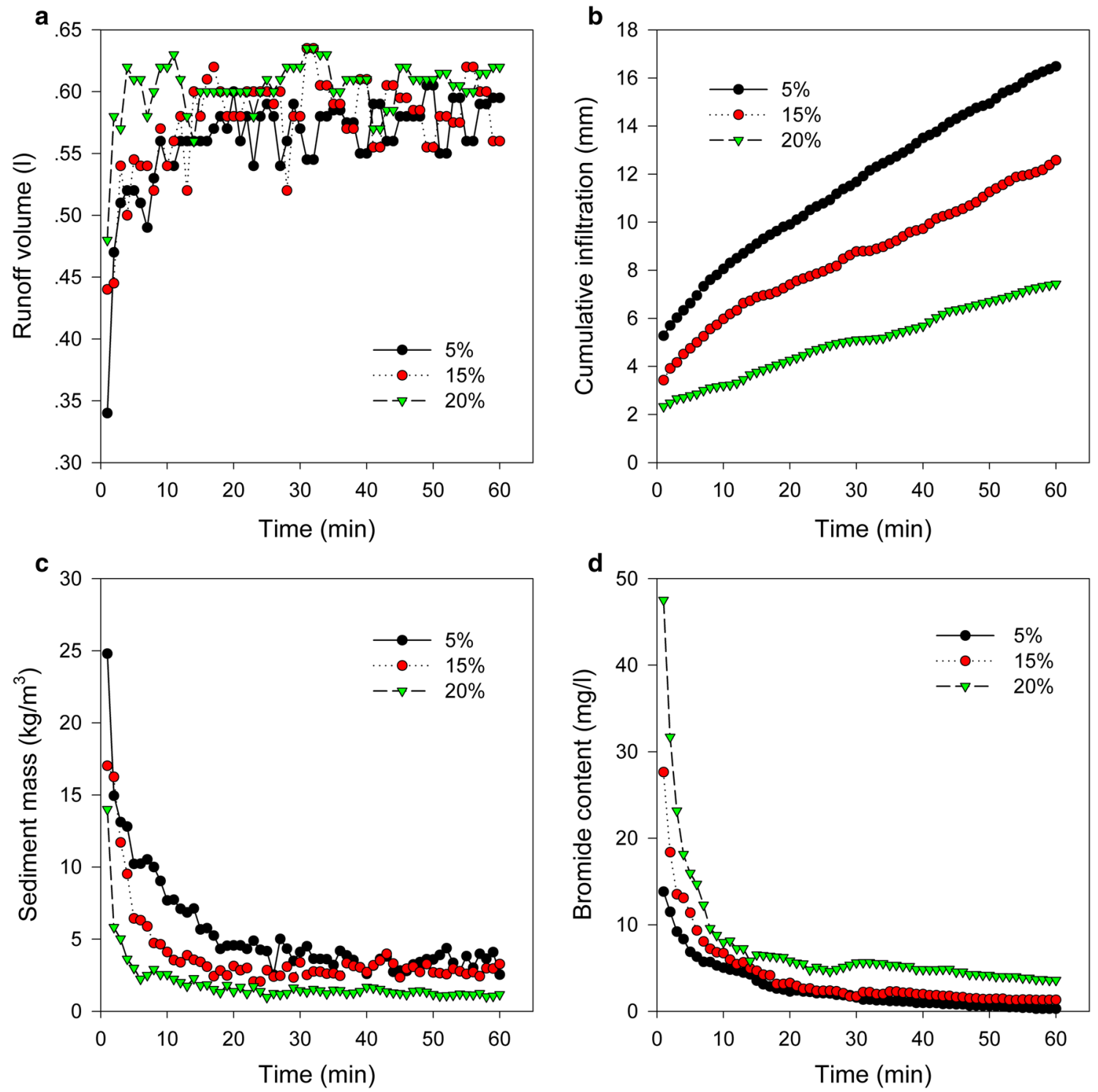

Fig. 2 Variation of the runoff rate and sediment and solute concentrations in the runoff over time for different initial soil moisture levels

Table 2 The time between the initiation of rainfall and the first observation of runoff (ponding time) and the cumulative infiltration during this time for different initial soil moisture content levels

\begin{tabular}{lll}
\hline $\begin{array}{l}\text { Initial soil moisture } \\
\text { content }(\%)\end{array}$ & $\begin{array}{l}\text { Ponding time } \\
(\mathrm{min})\end{array}$ & $\begin{array}{l}\text { Cumulative infiltration } \\
\text { during ponding time } \\
(\mathrm{mm})\end{array}$ \\
\hline 5 & 2.83 & 4.25 \\
15 & 1.83 & 2.75 \\
20 & 1.21 & 1.82 \\
\hline
\end{tabular}

caused increasingly early runoff formation at a given soil moisture content but also reduced the cumulative infiltration prior to runoff formation, as given in Table 3.
Table 3 The ponding time and the cumulative infiltration during this time at different rainfall intensities

\begin{tabular}{lll}
\hline $\begin{array}{l}\text { Rainfall intensity } \\
(\mathrm{mm} / \mathrm{h})\end{array}$ & $\begin{array}{l}\text { Ponding time } \\
(\mathrm{min})\end{array}$ & $\begin{array}{l}\text { Cumulative infiltration } \\
\text { during ponding time } \\
(\mathrm{mm})\end{array}$ \\
\hline 60 & 3.98 & 4.00 \\
96 & 2.41 & 3.84 \\
129 & 1.72 & 3.66 \\
\hline
\end{tabular}

The runoff volume, sediment mass and solute content for different rainfall intensities varied with time as shown in Fig. 3. Figure 3a shows that different rainfall intensities caused different runoff volume. The cumulative infiltration was nearly identical for all of the different rainfall intensities 

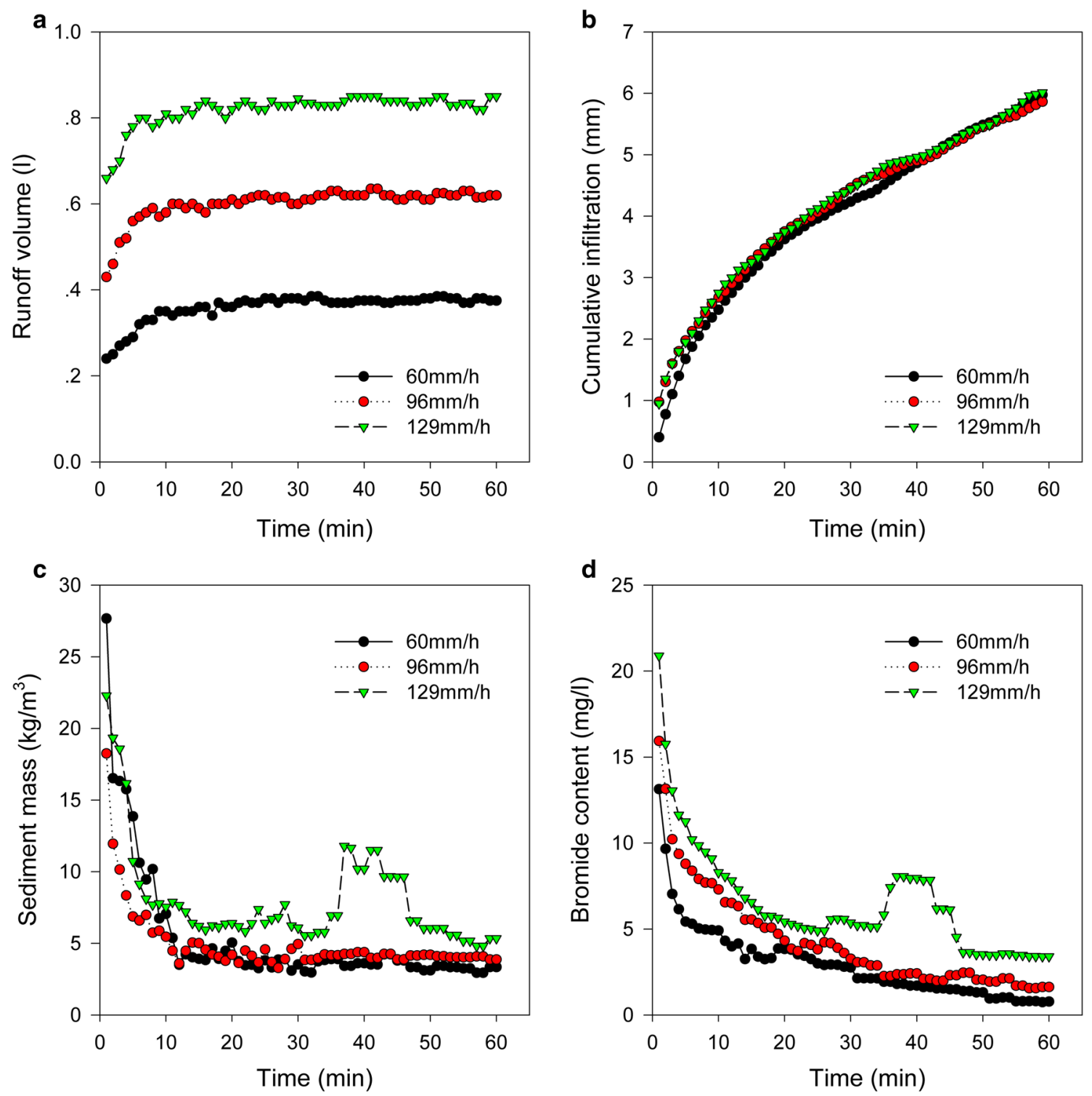

Fig. 3 Variation of the runoff rate and sediment and solute concentrations over time at different rainfall intensities

examined at any given initial soil moisture content, as shown in Fig. 3b. The mass of sediment in the runoff increased with increasing rainfall intensity and was much greater when the rainfall intensity was $129 \mathrm{~mm} / \mathrm{h}$ than under any other conditions examined (Fig. 3c). Thus, the results suggest that when the rainfall is sufficiently intense, its erosion capacity (together with that of the water flow) becomes stronger than the soil cohesion, causing rapid erosion.

As shown in Fig. 3d, increasing the rainfall intensity resulted in the increases in the runoff solute content. Although the runoff volume increased steadily after its initial formation, the runoff solute content decreased over time. Over the first few minutes of the runoff's existence, the runoff solute content decreased sharply as the rainfall intensity increased. Once the runoff content stabilized, heavier rainfall rates afforded higher runoff solute content. With respect to the time elapsed between the initiation of rainfall and the formation of the runoff, heavy rainfall was associated with a decrease in the cumulative infiltration, and so the quantity of solutes transported into the deeper soils by infiltration was reduced at higher rainfall intensities. In conjunction with the greater impact of raindrops and increased runoff flow under these conditions, this caused increases in the runoff solute concentration at higher rainfall intensities, as concluded by Wallach et al. (2001).

From Fig. 3d and c, it is apparent that when the rainfall intensity was $129 \mathrm{~mm} / \mathrm{h}$, there was a pronounced increase in the runoff solute content between 37 and 49 min after the initial formation of the runoff. And there still was a corresponding spike in the mass of sediment in the runoff between 
37 and 43-49 min, which indicated that soil erosion has a profound impact on the loss of solutes from the soil surface. All these results showed that obvious erosion of the surface soil took place at the bottom of the slope during the experiment, exposing deeper soil layers in which the solute concentrations were higher than the by-then thoroughly washed former surface layers. Consequently, the runoff solute content increased as these solutes were transferred from the soil under the influence of raindrop splashing and the runoff flow. Soil erosion thus promotes increased runoff solute content.

Figure $3 \mathrm{~b}$ shows that similar cumulative degrees of infiltration were observed under all three rainfall intensities. However, since the solute mass loss from the soil increased with the rainfall intensity, it seems that raindrops promote the transfer of solutes to the runoff and that rainfall splash has a profound effect on the loss of solutes to the runoff by virtue of its influence on the mass of sediment carried away by the flow (Fig. 3c).

\section{The effect of slope on the runoff volume, sediment mass and solute losses to the runoff}

The slope of the land is a very important factor in soil erosion. It directly affects the runoff velocity and runoff volume; increasing the gradient of the slope increases the erosion capacity of rain drops and water flow. Both the time between the initiation of rainfall and the formation of the runoff and the cumulative infiltration during this time decreased as the slope gradient increased (Table 4).

The runoff volume, sediment mass and solution content for different land slopes are shown in Fig. 4. The results indicate that solute loss is closely related to sediment loss (Catt et al. 1994; Hansen and Nielsen 1995; Hargrave and Shaykewich 1997; Teixeira and Misra 2005; Guo et al. 2010a, b). Increasing the slope gradient caused increases in the runoff volume and in the mass of sediment and content of solutes in the runoff. The runoff volume was greatest when the slope was $25^{\circ}$ and least when it was $5^{\circ}$, as shown in Fig. $4 \mathrm{a}$.

Increasing the land slope caused increases in the runoff volume and velocity and thus in the overall runoff volume. It also increased the water's capacity to erode, causing more soil to be eroded and entrained into the runoff

Table 4 The ponding time and the cumulative infiltration during this time for different slope gradients

\begin{tabular}{lll}
\hline Slope gradient $\left({ }^{\circ}\right)$ & Ponding time (min) & $\begin{array}{l}\text { Cumulative infiltration } \\
\text { during ponding time } \\
(\mathrm{mm})\end{array}$ \\
\hline 5 & 3.90 & 5.85 \\
15 & 3.29 & 5.00 \\
25 & 2.32 & 3.45 \\
\hline
\end{tabular}
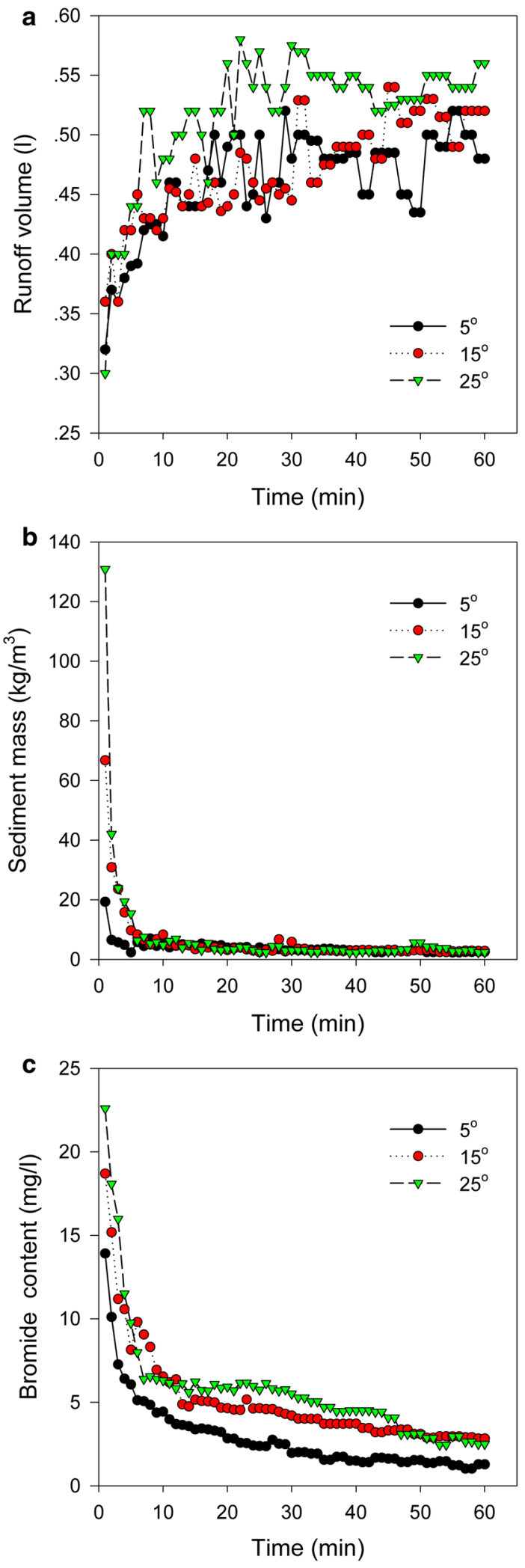

Fig. 4 Variation in the runoff rate and the concentrations of sediment and solute in the runoff over time for different slope gradients 
(Fig. 4b), increasing the runoff's solute content (Fig. 4c). At all time points examined, the solute content in the runoff when the slope was $25^{\circ}$ was about 2.08 times that when it was $15^{\circ}$, which in turn was 1.43 times that with a $5^{\circ}$ slope. The land slope affects the solute content in the runoff by controlling the mass of sediment in the runoff. Soil erosion thus plays an important role in solute losses to the runoff.

\section{The relationship between runoff volume, solute content and sediment mass}

Figure 5 shows that there was a near linear $\left(R^{2}>0.96\right)$ relationship between the cumulative sediment mass and the cumulative runoff volume under various different treatments, which is consistent with the conclusions of Guo et al. $(2010 \mathrm{a}, \mathrm{b})$. This pattern is similar to those observed in bare plots, in which there was a strong positive correlation between the runoff volume and soil loss (Huang and Bradford 1993; Flanagan et al. 2002; Benik et al. 2003). The greater the runoff volume per unit time, the greater the erosion capacity potential of the water flow and the mass of sediment in the runoff.

The relationship between the cumulative runoff solute mass and the cumulative sediment mass within the runoff appears to be linear, as shown in Fig. $6\left(R^{2}>0.67\right)$. This is consistent with the findings of other authors, who observed that the loss of soil chemicals is closely related to the loss of sediment (Catt et al. 1994; Hansen and Nielsen 1995; Hargrave and Shaykewich 1997; Teixeira and Misra 2005) and corroborates the results of Guo et al. (2010a, b).

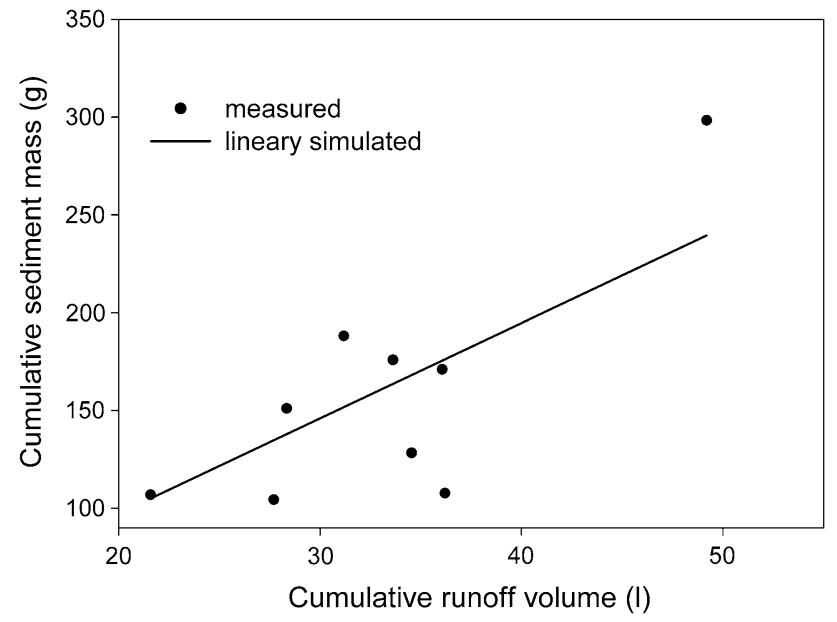

Fig. 5 Relationship between the cumulative sediment mass and cumulative runoff volume under different conditions

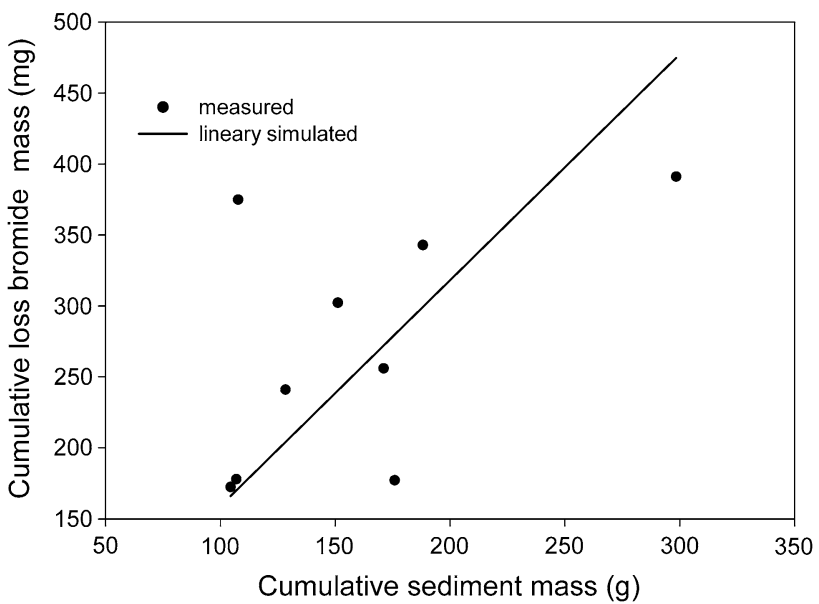

Fig. 6 Relationships between the cumulative runoff solute mass and the cumulative mass of sediment in the runoff under different conditions

\section{Ponding time effects}

The ponding time impacts the solute concentration in the soil profile and overland flow by controlling the cumulative infiltration. Figure 7 shows the effect of ponding time on solute concentration in the runoff for all treatments. The results indicate that the relationship between cumulative infiltration during ponding time and the solute concentration in the runoff at the first minute after runoff generation and the average solute concentration in the runoff can be well described by the negative linear equations (Fig. 7a, b).

In order to study the influents of infiltration during ponding time on the solute concentration in the soil surface layer when runoff took place, we took one-dimensional, vertical soil water movement equation (Richards' equation) to calculate water movement in the soil profile and advection-diffusion equation to calculate the solute transport within the soil profile during ponding time with model (Dong et al. 2013). Take the bromide as a tracer because the parameters of bromides are easier to obtain.

From the model (Dong et al. 2013), the solute concentration in the soil surface could be obtained when runoff took place. Our results demonstrated that the bromide concentration in the soil surface when runoff took place was negative linear correlation with the cumulative infiltration during ponding time (Table 5, Fig. 8a). Solute concentration in the runoff at the first minute when runoff took place and the average solute concentration in the runoff were positive linear correlation with solute concentration in the soil surface when runoff took place as shown in Fig. 8b, c and given in Table 5. 


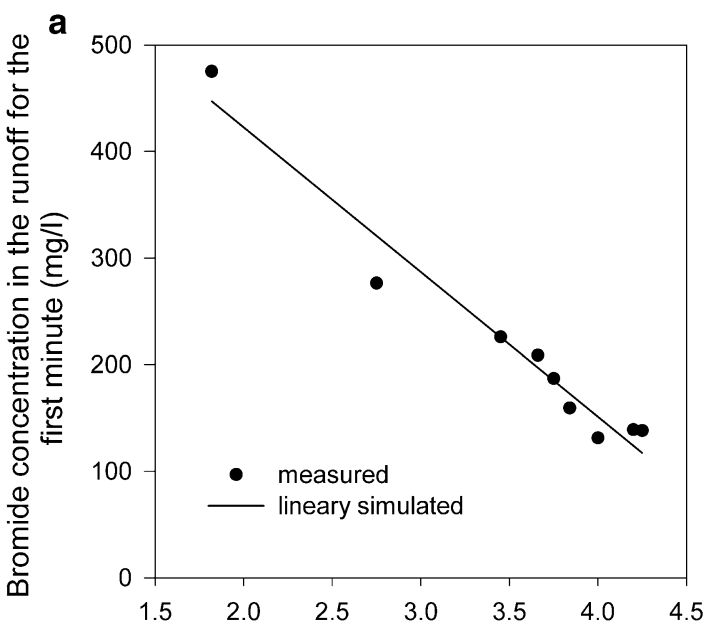

Cumulative infiltration during ponding time $(\mathrm{mm})$

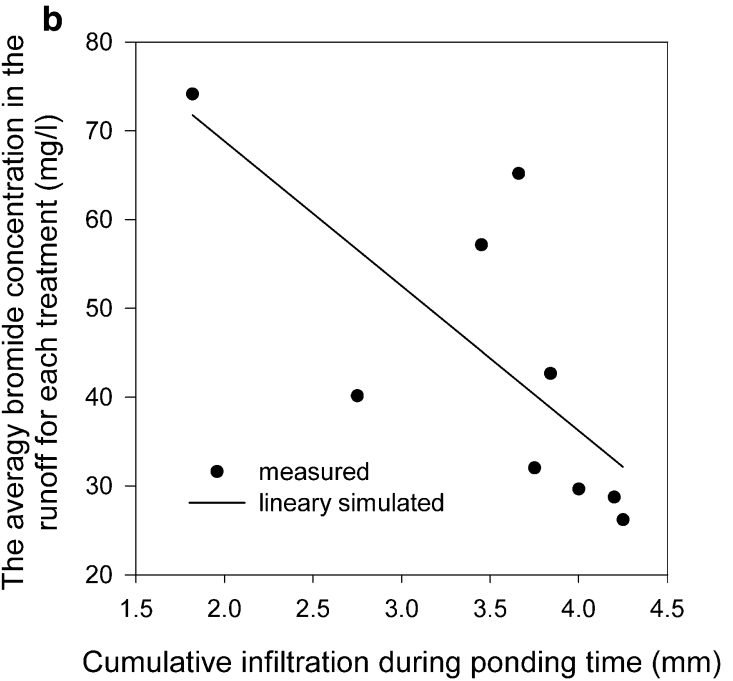

Fig. 7 Relationships between the cumulative infiltration during ponding time $(I)$ and solute concentration in the runoff at first minute $\left(C_{1}\right)$, the average solute concentration in the runoff $(\mathrm{Ca})$

Table 5 The relationships between each of the variables (bromide concentration in the runoff for the first minutes $C_{l}$. Cumulative infiltration during ponding time $I$. Average bromide concentration in the runoff for each treatment $\mathrm{Ca}$. Soil surface solute concentration when runoff took place $C s$.) which were caused by the different ponding times

\begin{tabular}{lll}
\hline & Simulate equations & $R^{2}$ \\
\hline Relationship between $C_{I}$ and $I$ & $C_{I}=-135.69 I+693.98$ & 0.96 \\
Relationship between $C a$ and $I$ & $C a=-16.296 I+101.43$ & 0.53 \\
Relationship between $C s$ and $I$ & $C s=-290.37 I+1549.4$ & 0.82 \\
Relationship between $C_{l}$ and $C s$ & $C_{I}=0.409 C s+0.461$ & 0.89 \\
Relationship between $\mathrm{Ca}$ and $C s$ & $C a=0.055 C s+14.88$ & 0.63 \\
\hline
\end{tabular}

\section{Conclusions}

The initial soil moisture content influences solute loss by virtue of its impact on infiltration, which suggests that if infiltration could be facilitated, the loss of solutes could be increased. Rainfall intensity increases the mass of sediment carried away by the runoff and decreases the time required for runoff formation; the latter in turn increases the solute content in the surface layer. The slope gradient also has a significant influence on the masses of solute and sediment in the runoff; both increase as the slope gets steeper.
Fig. 8 Relationships between the solute concentration in the soil surface when runoff begins $(C s)$ and cumulative infiltration during ponding time, solute concentration in the runoff at first minute $\left(C_{1}\right)$, the average solute concentration in the runoff for each treatment $(\mathrm{Ca})$

The cumulative sediment mass and cumulative runoff volume can be accurately modeled using linear equations. The solute content in the runoff is strongly correlated with the mass of sediment in the runoff. The cumulative infiltration before runoff formation has a strong influence on the solute losses to the runoff by controlling the solute content in the soil surface when the runoff took place. The relationship between cumulative infiltration during ponding time and the solute content in the runoff at the first minute after runoff generation, and the relationship between cumulative infiltration during ponding time and the average solute content in the runoff, can be well described by the linear equations. The solute content in the soil surface when runoff took place was negative linear correlation with the cumulative infiltration during ponding time. Solute content in the runoff at the first minute when runoff took place and the average solute content in the runoff were positive linear correlation with solute content in the soil surface when runoff took place. 


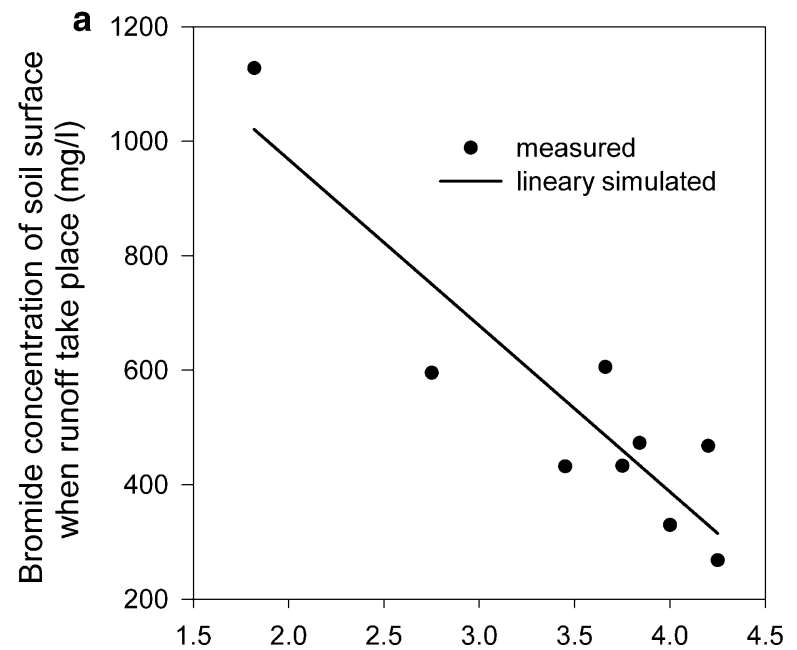

Cumulative infiltration during ponding time $(\mathrm{mm})$

b

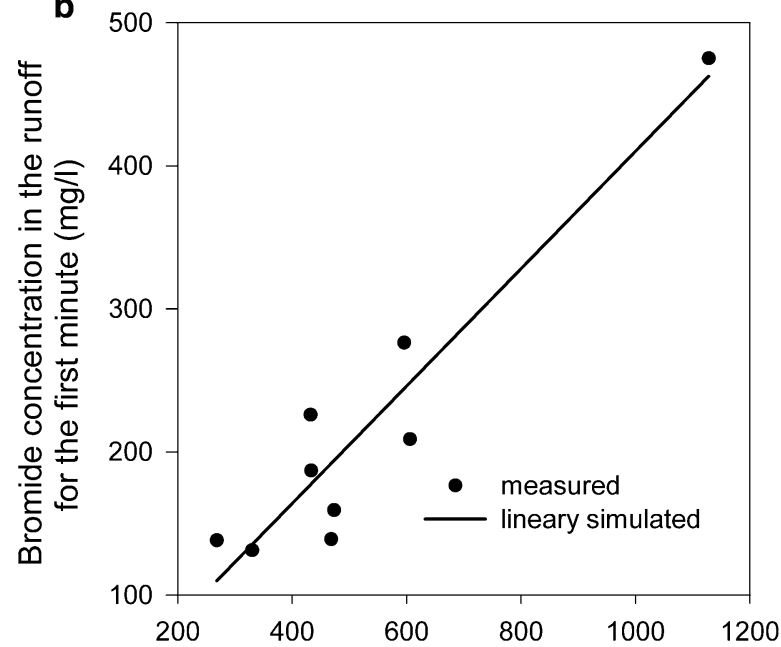

Bromide concentration of soil surface when runoff take place $(\mathrm{mg} / \mathrm{l})$

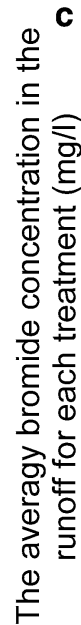

c

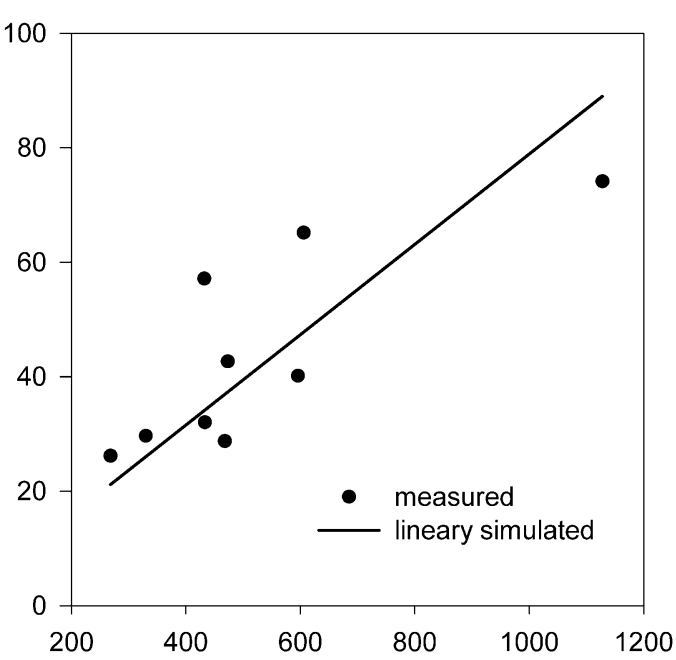

Bromide concentration of soil surface when runoff take place $(\mathrm{mg} / \mathrm{l})$
Acknowledgements This research was supported by the projects of the Heilongjiang Provincial Department of Education Science and Technology Research Project (12541039). We thank the reviewers and editors for their suggestions and helpful comments.

Open Access This article is distributed under the terms of the Creative Commons Attribution 4.0 International License (http://creativeco mmons.org/licenses/by/4.0/), which permits unrestricted use, distribution, and reproduction in any medium, provided you give appropriate credit to the original author(s) and the source, provide a link to the Creative Commons license, and indicate if changes were made.

\section{References}

Ahuja LR, Sharpley AN, Yamamoto M et al (1981) The depth of rainfall-runoff-soil interaction as determined by 32P. Water Resour Res 17(4):969-974

Benik SR, Wilson BN, Biesboer DD et al (2003) Performance of erosion control products on a highway embankment. Trans Am Soc Agric Eng 46(4):1113-1119

Catt JA, Quinton JN, Rickson RJ et al (1994) Nutrient losses and crop yields in the Woburn erosion reference experiment. In: Rickson RJ (ed) Conserving soil resources European perspective. CAB International, Oxford, pp 94-104

Dong WC, Wang QJ (2013) Modeling soil solute release into runoff and transport with runoff on a loess slope. J Hydrol Eng $18: 527-535$

Dong WC, Wang QJ, Zhou BB et al (2013) A simple model for soil dissolved chemicals transport with runoff by raindrops. CATENA 101:129-135

Flanagan DC, Chaudhari K, Norton LD (2002) Polyacrylamide soil amendment effects on runoff and sediment yield on steep slopes: part I. Simulated rainfall conditions. Trans Am Soc Agric Eng 45(5):1327-1337

Gao B, Walter MT, Steenhuis TS, Hogarthb WL et al (2004) Rain induced chemical transport from soil to runoff: theory and experiments. J Hydrol 295:291-304

Guo TL, Wang QJ, Li DQ et al (2010a) Effect of surface stone cover on sediment and solute transport on the slope of fallow land in the semi-arid loess region of northwestern China. J Soils Sediments 10:1200-1208

Guo TL, Wang QJ, Li DQ et al (2010b) Sediment and solute transport on soil slope under simultaneous influence of rainfall impact and scouring flow. Hydrol Process 24:1446-1454

Hansen AC, Nielsen JD (1995) Runoff and loss of soil and nutrients. In: Correll A (ed) Surface runoff erosion and loss of phosphorus at two agricultural soils in Denmark. Danish Institute of Plant and Soil Science, Tjele, pp 149-188

Hargrave AP, Shaykewich CF (1997) Rainfall induced nitrogen and phosphorus losses from Manitoba soils. Eur J Soil Sci 77:59-65

Huang CH, Bradford JM (1993) Analyses of slope and runoff factors based on the WEPP erosion model. Soil Sci Soc Am J 57(5):1176-1183

McDowell LL, Willis GH, Murphree CE (1984) Plant nutrient yields in runoff from a Mississippi delta watershed. Trans ASAE 27:1059-1066, 1073

Menzel RG, Hoades EDR, Olness AE et al (1978) Variability of annual nutrient and sediment discharges in runoff from Oklahoma cropland and rangeland. J Environ Qual 7:401-406

Schuman GE, Burwell RE, Piest RF et al (1973a) Nitrogen losses in surface runoff from agriculture watersheds in Missouri Valley loess. J Environ Qual 2:299-302 
Schuman GE, Spomer RG, Piest RF (1973b) Phosphorus losses from four agricultural watersheds in Missouri Valley loess. Soil Sci Soc Am Proc 37:424-427

Teixeira PC, Misra RK (2005) Measurement and prediction of nitrogen loss by simulated erosion events on cultivated forest soils of contrasting structure. Soil Tillage Res 83:204-217

Wallach R, Grigorin G, Rivlin J (2001) A comprehensive mathematical model for transport of soil-dissolved chemicals by overland flow. J Hydrol 247:85-99

Walter MT, Gao B, Parlange JY (2007) Modeling soil solute release into runoff with infiltration. J Hydrol 347:430-437

Wang QJ, Wang WY, Shen B et al (1998) Interacting depth of rainfallrunoff-soil solute. J Soil Erosion Water Conserv 2(4):41-46

Wang QJ, Horton R, Shao MA (2002a) Effective raindrop kinetic energy influence on soil potassium transport into runoff. Soil Sci 167(6):369-376
Wang QJ, Horton R, Shao MA (2002b) Horizontal infiltration method for determining Brooks-Corey model parameters. Soil Sci Am J 66:1733-1739

Wang H, Wang QJ, Shao MA (2006) Laboratory experiments of soil nutrient transfer in the loess slope with surface runoff during simulated rainfall. Trans CSAE 22(6):39-44

Yang T, Wang QJ, Xu D et al (2015) A method for estimating the interaction depth of surface soil with simulated rain. CATENA 124:109-118

Yang T, Wang QJ, Liu YL et al (2016) A comparison of mathematical models for chemical transfer from soil to surface runoff with the impact of rain. CATENA 137:191-202

Publisher's Note Springer Nature remains neutral with regard to jurisdictional claims in published maps and institutional affiliations. 